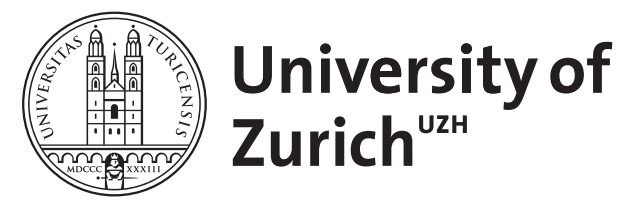

\title{
The dissociative and polemical political: Chantal Mouffe and the intellectual heritage of Carl Schmitt
}

\author{
Beckstein, Martin
}

\begin{abstract}
In her more recent work, Chantal Mouffe enters into what she calls a 'dialogue' with Carl Schmitt on the political. So far, interpretations of this dialogue suggest that Mouffe attempts to revise Schmitt's friend/enemy-distinction and carve out a theory of agonistic pluralism. An interpretation on these grounds, this article argues, reduces the dialogue to its analytical dimension and cannot comfortably be upheld. Mouffe indeed appropriates Schmitt's friend/enemy-distinction, but she also gets inspired by the metatheoretical facet of his intellectual heritage with the result that her theory becomes organically interwoven with a polemical dimension. Rather than aiming at a post-structuralist defanging of Schmitt's conception of the political, Mouffe recontextualizes and applies it to the current academic discourse, for this allows decontesting her radical pluralist cause by establishing a we/them opposition along a political/post-political divide.
\end{abstract}

DOI: https://doi.org/10.1080/13569317.2011.540941

Posted at the Zurich Open Repository and Archive, University of Zurich

ZORA URL: https://doi.org/10.5167/uzh-50536

Journal Article

Accepted Version

Originally published at:

Beckstein, Martin (2011). The dissociative and polemical political: Chantal Mouffe and the intellectual heritage of Carl Schmitt. Journal of Political Ideologies, 16(1):33-51.

DOI: https://doi.org/10.1080/13569317.2011.540941 


\title{
The Dissociative and Polemical Political
}

\section{Chantal Mouffe and the Intellectual Heritage of Carl Schmitt}

\author{
Martin Beckstein
}

\begin{abstract}
In her more recent work, Chantal Mouffe enters into what she calls a 'dialogue' with Carl Schmitt on the political. So far, interpretations of this dialogue suggest that Mouffe attempts to revise Schmitt's friend/enemydistinction and carve out a theory of agonistic pluralism. An interpretation on these grounds, this article argues, reduces the dialogue to its analytical dimension and cannot comfortably be uphold. Mouffe indeed appropriates Schmitt's friend/enemy-distinction, but she also gets inspired by the metatheoretical facet of his intellectual heritage to the result that her theory becomes organically interwoven with a polemical dimension. Rather than aiming at a poststructuralist defanging of Schmitt's conception of the political, Mouffe recontextualizes and applies it to current academic discourse, for this allows decontesting her radical pluralist cause by establishing a we/them opposition along a political/post-political divide.
\end{abstract}

Keywords: Chantal Mouffe; Carl Schmitt; friend/enemy-distinction; agonistic pluralism; polemics; the political

Word count: 10089 


\section{Introduction $^{1}$}

After World War II Carl Schmitt has long been a red rag to scholars because of his complicity with National Socialism, and up to the present day especially democratic theorists make strenuous efforts to avoid being linked to his thought. Chantal Mouffe, in contrast, is among those few who emphasize the benefits of reconsidering his work. 'Not the moral qualities', she says, 'should be the decisive criteria when deciding whether we need to establish a dialogue' with a thinker's work, but 'the intellectual force'. ${ }^{2}$

Since the mid 1990s, Mouffe has established such a dialogue in her writings. ${ }^{3}$ The interpretation thereof appears very much straightforward: Mouffe attempts to analytically revise Schmitt's friend/enemy-distinction along poststructuralist and nonessentialist lines in order to provide a viable theory of democracy. The result is 'agonistic pluralism', which claims to come to terms with Schmitt's insight that conflictuality among groups determines our ontological condition while at the same time providing the conceptual key which allows for a differential treatment of conflictuality. In the secondary literature, there are considerable discussions on whether Mouffe's agonistic pluralism successfully accomplishes such a goal. Actually, most think that it does not. Yet, although commentators have provided different and not always mutually compatible criticisms, they do not examine whether Mouffe's scholarly goal is adequately grasped in the first place. Commentators conspicuously concur in suggesting that Mouffe's dialogue with Schmitt is sufficiently understood if characterized as an analytical revision of the friend/enemy-distinction, more precisely, as the attempt of a poststructuralist defanging. ${ }^{4}$ 
Intuitively, it is uncontroversial to read the dialogue in traditional analytical terms, if only because the method of scrutinizing another writer's conceptual apparatus, revealing inherent problems, trying to tackle them, and deducing implications is a standard procedure in the discipline of political theory. Additional credence is lent to this interpretation since Mouffe herself abets it in many places. Schmitt's thought, she justifies her entering into a dialogue, contains crucial insights into the political and reveals basic flaws of liberalism; and answering Schmitt's challenge means 'devising ways in which antagonism can be transformed into agonism'. Although I have no doubts that a reconceptualization of Schmitt's friend/enemy-distinction is an important part of a convincing interpretation of Mouffe's dialogue with Schmitt, I argue that it cannot comfortably be reduced to this dimension. Scrutinizing her writings against the backdrop of the theoretical peculiarities of her account and Schmitt's multi-faceted intellectual heritage leads us instead to modify our interpretation of the dialogue. We come to detect a polemical facet that - rather than supplementing the analytical dimension - is organically interwoven with it and culminates in a theorization of the political which is dissociative in conceptual character and scholarly gesture. ${ }^{6}$

To set out my argument, I first sketch the contours of the analytical dimension of Mouffe's dialogue with Schmitt, mostly on her own terms. Then, I discuss three criticisms that have been formulated by commentators. Not only do they help to understand better her theory of agonistic pluralism; they also reveal that Mouffe arrives at surprisingly different conclusions from Derrida in his deconstruction of the friend/enemy-distinction. In the third section, I search for an explanation for this oddity and call to mind the metatheoretical facet of Schmitt's intellectual heritage. I argue that Mouffe 
appropriates Schmitt's friend/enemy-distinction in his anthropomorphic conceptualization because she also gets inspired by his remarks about the polemical nature of political theorizing in general, and theorizing the political in particular.

Before preparing the ground for my argument by reconstructing Mouffe's theory of agonistic pluralism, it should be noted that Mouffe is not the first to theorize about the political under the term 'agonistic pluralism', or very similar ones. Moreover, the conceptions of agonistic pluralism brought forward by scholars such as William Connolly, Bonnie Honig, or James Tully significantly diverge from Mouffe's account theoretically inasmuch as in terms of adherence to philosophical traditions, as well as, arguably, with regard to the purposes to which the theories are put to use. My exclusive interest is in Mouffe's variant, and the interpretation of her dialogue with Schmitt through which she arrives at it. ${ }^{7}$

\section{Thinking with, against, and beyond Schmitt: the analytical dimension}

In his essay The Concept of the Political Schmitt argues that in order to understand the political we must investigate its specific ultimate distinction just the way we proceed when determining the moral, the aesthetic, or the economic. Whereas the moral, the aesthetic, and the economic are traditionally explained in terms of good and evil, beautiful and ugly, and profitable and unprofitable, there should be a likewise special, independent, and somewhat obvious criterion of the political. While Max Weber could not imagine a constitutive distinction along these lines for the political, ${ }^{8} \mathrm{Schmitt}$ is not lost for an answer. The fundamentum divisionis of the political, he tells us, is the distinction between friend and enemy. ${ }^{9}$ 
Mouffe considers Schmitt's conception of the political still pertinent. Thinking with Schmitt, she points out, we can instantaneously gain three basal insights: first, the political does not constitute a specific sphere or level of society, but determines our ontological condition. ${ }^{10}$ Second, the subjects of the political are collectives. The political concerns the moment of the association/dissociation of groups of people. ${ }^{11}$ Finally, political relations are necessarily conflictual. Interests of competitors or disagreement of discussants might be resolved by means of negotiation or deliberation. Political oppositions, however, foreclose any rational consensus. By determining the political as the distinction between friend and enemy, Schmitt anticipates the poststructuralist insight into the relational nature of identities according to which the precondition for the existence of any identity is something other that constitutes its exterior. The construction of a 'we', Mouffe tells us, requires the demarcation of a 'them' which serves as its 'constitutive outside' in the process of identity-formation. ${ }^{12}$ Taken together, Schmitt's conception of the political reveals that whoever sympathizes with the overcoming of factionism (especially by means of an all-inclusive, rational consensus) indulges in wishful thinking because conflict is constitutive of the intercourse of political collectives and thus ineradicable from social life.

Despite these crucial insights into the political, however, Mouffe feels a strong anti-pluralist bias looming in Schmitt's conception which requires her to part company with him. '[T]he main limitation of Schmitt's friend/enemydiscrimination', she argues, 'is that while he asserts the conflictual nature of the political, he does not permit a differential treatment of this conflictuality'. ${ }^{13}$ As a result, the only feasible and legitimate pluralism is a pluralism of states. ${ }^{14}$ In these remarks, Mouffe alludes to a wide-spread 
criticism against Schmitt's conception. Since she does not repeat it in detail, some brief explanations will be helpful to recall the reproach.

According to many critics, Schmitt determines political oppositions in not simply a conflictual, but in fact bellicose way. ${ }^{15}$ Whereas most approaches that envisage politics 'sub specie belli' and not 'sub specie consensus' treat conflict primarily as standing metaphorically for pluralist political intercourse, ${ }^{16}$ 'bellum' in Schmitt's account gains a surprisingly literal meaning. Politics is close to being identified with war. The opposition of friend and enemy does not mean:

'competition, nor does it mean pure intellectual controversy nor symbolic wrestlings in which, after all, every human being is somehow always involved, for it is a fact that the entire life of a human being is struggle and every human being symbolically a combatant. The friend, enemy, and combat concepts receive their real meaning precisely because they refer to the real possibility of physical killing, ${ }^{17}$

Admittedly, Schmitt makes some efforts to avoid conflating the conflictual reality of the political with war. On the one hand, he attempts to reduce physical killing to an 'ever present possibility' or the 'leading presupposition' of the political. ${ }^{18}$ On the other hand, he distances himself from Clausewitz's dictum that war is the continuation of politics by other means. However, although his reasoning is conclusive to a great extent, neither remark is ultimately capable of dispelling concerns about the bellicose tendency.

The first reservation faces a logical inconsistency. Schmitt singles out the friend/enemy-distinction precisely because it is alone capable of escalating into warlike antagonism. In order to be political, Schmitt asserts, an 
opposition must necessarily comprise the possibility of erupting into violence. Thus, Schmitt confers on war a teleological dimension. War turns out to be the essence and the goal, the eventuality, and not a mere possibility of the political. ${ }^{19}$ The centrality of physical killing for Schmitt's conception of the political is pointedly revealed by his treatment of pacifism. Pacifists cannot become a political movement, he wants to make us believe, as long as they are pacifist. They will group themselves as friends against enemies (the nonpacifists) only when their opposition reaches the necessary grade of intensity and resolve, that is, when they are prepared to actually conduct 'war against war'. ${ }^{20}$

Schmitt's other remark, the repudiation of Clausewitz's infamous dictum, is a diversionary tactic. After having rejected it nominally, he laments in a footnote that the dictum is generally cited incorrectly. ${ }^{21}$ Following his comment it turns out that Schmitt refrains from considering war as the continuation of politics simply because tactics in diplomatic negotiations differ from those on the battleground. Apart from the reference to tactical differences, there is deafening silence. Differentiations on conceptual or normative grounds apparently are deemed dispensable. The goal of war and politics for Schmitt is the same. Thus, in fact agreeing with Clausewitz, it comes without surprise that in a 1938 corollary to The Concept of the Political Schmitt unhesitatingly affirms the dictum and even inflects it: expressing his anger about the 'peace dictate of Versailles' ('Pariser Friedensdiktate') he avers that the politics of diplomacy is just another form of continuing war by other means, and in fact a particularly perfidious one. ${ }^{22}$

For the task of developing a viable theory of democracy the bellicose teleology in Schmitt's conception of the political is evidently unfavourable. If 
political oppositions are part of our ontological condition and are eventually staged violently, there is no place for pluralism inside a community. If the community is not to get caught up in turmoil, political conflict must be externalized. In short, Schmitt's conception 'requires expelling every division and antagonism outside the demos' ${ }^{23}$

To adjust the friend/enemy-distinction with a model of democracy requires going beyond Schmitt and theorizing the political sub specie belli while nevertheless allowing for the possibility of (non-violent) pluralism inside a community. The challenge of Carl Schmitt, Mouffe affirms subsequently, consists in finding the conceptual means to transform antagonism into agonism:

'If we want to acknowledge on one side the permanence of the antagonistic dimension of conflict, while on the other side allowing for the possibility of its »taming «, we need to envisage a [...] type of relation which I have proposed to call »agonism«. While antagonism is a we/they relation in which the two sides are enemies who do not share any common ground, agonism is a we/they relation where the conflicting parties $[\ldots$ share $]$ a common symbolic space within which the conflict takes place' ${ }^{24}$

Some commonality among people is required, Mouffe admits, to allow treating the members of the opposed collective not in terms of enemies to be destroyed but as adversaries to be confronted, and thus to prevent the disruption of society. But the necessary common bond does not need to be a common good, which would, after all, undermine pluralism. ${ }^{25}$ The condition of possibility of non-violent intercourse within a political community is 
neither a substantive consensus (as Schmitt holds according to her reading) nor a rational consensus (as Mouffe claims Rawls and Habermas would have it). A 'conflictual consensus', she says, will do. ${ }^{26}$ The respect of mutual democratic citizenship is commonality enough to mitigate political conflicts, and it is a commonality that is compatible with substantive forms of heterogeneity. Citizens of democratic communities, Mouffe argues, envisage the opponent as adversary when confronting each other and thus enable 'religious, moral and cultural pluralism, as well as a pluralism of political parties' $^{27}$

If that is a rather uncontroversial summary of the analytical claims made in Mouffe's dialogue with Schmitt, then her agonistic pluralism promises to be an attractive 'realistic' theory of democracy. Apparently, it grounds Schmitt's friend/enemy-distinction in poststructuralist insights, and corroborates that political identities form relationally and, for that matter, turn out to be inherently conflictual. The institutionalization of an adversarial model of politics in the left/right format under a 'conflictual consensus' is proposed to be the key for the mitigation of conflict. Though irresolvable, the conflict of political collectives can take on agonistic forms. Any attempt to block the channels through which the political collective(s) from the right and the left can stage their conflicts, however, means abolishing the conflictual consensus and undoing the conditions of possibility of agonistic conflict. The implication to be deduced, it is suggested, is that whoever works toward the realization of a politics 'beyond left and right', 'contributes to exacerbating the antagonistic potential existing in society' ${ }^{28}$

Commentators of Mouffe's dialogue with Schmitt certainly provide slightly different summaries of Mouffe's claims. Also, certain variations in 
hermeneutic observation might be found. Notably, however, the scholarly interest in Mouffe's dialogue with Schmitt has been primarily a systematic one so far, to the result that the dialogue is portrayed to be coextensive with her theory of agonistic pluralism. More than the question of the interpretation of Mouffe's dialogue, the assessment of the analytical quality of her dealing with Schmitt's conception of the political has caused controversy. I will review three critical assessments which, on the one hand, contribute most to enhancing our understanding of Mouffe's theoretical reconsideration of the friend/enemy-distinction and whose adequacy, in my view, increases in the presented order. On the other hand, discussing these three charges leads us to question that there is nothing important to be said about Mouffe's dialogue with Schmitt apart from her variant of agonistic pluralism. The most accurate criticism, in fact, implies that neither this theory nor her dialogue with Schmitt on the political more generally can be understood unless a dimension, complementary to the analytical one, is taken into consideration.

\section{Critical encounters}

(a) According to the first assessment, Mouffe attempts to analytically morph antagonism into agonism by means of the 'conflictual consensus'; in other words, she attempts to transform Schmitt's conception of the political into a friend/adversary-distinction. While she certainly sanitizes Schmitt, the argument runs, she can do so only by departing from antagonism as the constitutive feature of the political. ${ }^{29}$ Why exactly should opposed groups refrain from using violence when staging their conflicts? The mitigation of antagonism could be accomplished, of course, on the basis of habits (people are used to dispense with violence), or a regulative idea (e.g. the Kantian one 
that informs Habermas's communicative ethics), or a voluntary and rational agreement (e.g. people believe that they can most effectively oppose their adversaries under the aegis of the electoral game). By drawing on one of these solutions, however, a theory of agonistic pluralism succumbs to the liberal 'flaws' of setting hopes in an overall consensus without exclusions she criticizes in the first place. So, does Mouffe's pluralist agonism silently shift into a rationalist and universalistic approach to politics sub specie consensus? Does her attempt to transform the enemy into an adversary fail?

On some occasions one easily gets this impression; for instance, where Mouffe portrays antagonism no longer as permanent, ineradicable, or irreducible but instead as an 'ever present possibility', or a 'potential present in human relations'; ${ }^{30}$ or where she advances her argument on the terrain of international relations and calls for a 'truly global' Jus Publicum Europaeum. ${ }^{31}$ But actually it does not. The attempt does not fail, though, because Mouffe does not aim at generally transforming antagonism into agonism. She is explicit about that: 'A democratic society cannot treat those who put its basic institutions into question as legitimate adversaries'. ${ }^{32}$ That 'the opponent is to be considered as an adversary whose existence is legitimate and must be tolerated,' applies only 'within the context of the political community'; in turn, '[t]he category of the »enemy« [...] remains pertinent with respect to those who do not accept the democratic »rules of the game $\ll .{ }^{33}$ Hence, due to the shared opposition against a superordinate enemy, the conflicts among the members of the democratic community are mitigated and can take on agonistic forms. However, religious fundamentalists, chauvinists, or recalcitrant aristocrats - in a word, all those that have a firstorder commitment to values other than the pluralist-democratic ones - are not 
adversaries but enemies; and if they are not to be destroyed, then at least they need to be excluded from the democratic community.

The first criticism exposes ambiguities but does not perfectly apply because the category of the enemy remains pertinent. Regarding the understanding of agonistic pluralism, therefore, we should expect that Mouffe's conceptual modification of Schmitt's conception of the political has to be located primarily on the side of the in-group: Mouffe's adversaries as compared with Schmitt's friends; the point being to convert the friend/enemydistinction not into a friend/adversary-distinction but into an adversary/enemy-distinction. As noted before, Mouffe indeed claims that her approach allows for substantive oppositions inside a political community whereas Schmitt's theory allegedly calls for a homogeneous demos and only accepts a pluralism of states. If so, however, a second criticism comes into play. Were the gist of Mouffe's theory of agonistic pluralism that political collectives within a democratic community can oppose each other in nonviolent terms insofar as they acknowledge the existence of a common and comparatively greater enemy, then doubts arise whether this is a significant theoretical innovation. ${ }^{34}$

(b) Mouffe's reading of Schmitt is not very generous. On the one hand, she suggests that the only political units Schmitt envisages are states whose citizens are internally united as friends and externally opposed to other states as enemies (cf. endnote 14). In the very first pages of The Concept of the Political, however, Schmitt is straightforward in rejecting state-centric conceptions of the political. ${ }^{35}$ Moreover, after World War II Schmitt explicitly acknowledges a diversity of political actors. The partisan, not to forget, is then one of his political actors par excellence. ${ }^{36}$ 
On the other hand, considerable doubts arise as to whether Mouffe's conception really allows for a domestic pluralism of higher quality. In The Concept of the Political, Schmitt traces situations when no pluralism could be found within a political community. In times of absolutism the state had the monopoly over the political; 'the political', as Oliver Marchart explains Schmitt's view, was 'a matter only of the external politics between states, while internal politics turn[ed] into a question of policing an already established order'. ${ }^{37}$ Apart from that there existed only pseudo-political forms of politics that Schmitt calls 'Politesse' or 'petite politique,' i.e. courtly intrigues. ${ }^{38}$ Yet under conditions of a democratic community such as the Weimar Republic, Schmitt affirms, significant (non-violent) antagonisms exist within the domestic realm, too. He refers to the pluralism of pressure groups in the struggle over policies, and especially party politics. ${ }^{39}$ There is little reason to believe that Schmitt's conception forecloses pluralism within nonabsolutist political communities.

To be sure, it needs to be stressed that for Schmitt these domestic conflicts are less fundamental than the sovereign's decision about the order of the political community and its enemies. But at the same time we have perfect reason to conclude that for Schmitt in political regimes other than absolutist monarchies there do actually exist political oppositions in the domestic realm, and that the activities of political collectives within the state cause considerable effects on the constitution of the political community: 'the state encompasses and relativizes all these antitheses. However an antithesis and antagonism remain here within the state's domain which have relevance for the concept of the political'. 40 
Internal conflicts for Schmitt are the expression of friend/enemygroupings even if they are only of a secondary quality. Yet, the point is that the pluralism Mouffe imagines within a democratic political community is likewise secondary with regard to the political. Because she leaves largely untouched the category of the enemy, the primary political opposition continues to persist between the community's identity and its 'constitutive outside': between the pluralist democrats and those who put into question the institutions of the community by not accepting the democratic rules of the game. Schmitt's friends are renamed adversaries. What Schmitt calls homogeneity, Mouffe calls commonality. And what for Schmitt is ensured by race, the nation, a religious conviction, arête, or civic virtue, ${ }^{41}$ for Mouffe is provided by the democratic rules of the game, ethico-political principles of liberal democracy, res publica, or the assertion of liberty and equality for all. ${ }^{42}$ There are differences, of course, but they are modest since the decisive criterion for both is that the common bond is strong enough to unite people in an alliance against an outside political collective. The primary friend/enemydistinction is drawn between different communities. Domestic pluralism for both is legitimate and possible, though in the last instance secondary.

It is not beyond reason to maintain, therefore, that a theory of pluralist agonism could already be found in Schmitt with a more generous reading. Just as there is no striking difference regarding the quality of domestic pluralism, also those scattered formulations that suggest a general taming of antagonism very much parallel the later Schmitt's own attempts to extricate first order political conflict - inimical opposition - from war. ${ }^{43}$ Finally, perhaps, one may wonder whether it is by chance that Schmitt already contemplates the possibility of mitigated, adversarial political conflict by introducing the term 
agonism. In a corollary to the 1963 German edition of The Concept of the Political, Schmitt derives the German word 'Feind' from 'Fehde' (engl.: feud, vendetta), and explains that in the middle-ages 'Fehde' was differentiated into 'knightly and non-knightly feud'. 'The knightly feud', he continues, 'leads to fixed forms and thereby to confront the feud opponent in an agonistic way' ${ }^{4}$

While Mouffe's agonistic pluralism turns out to be more indebted to Schmitt's conception of the political than one might have expected, there is of course no point in denying Mouffe's analytical accomplishments. As a reading of Schmitt's thought, after all, it is sufficiently selective that many political theorists consider it as exceptionally thought-provoking, while other scholars find it 'deadly wrong' because they see in Schmitt's work essentially a rejection of political philosophy in the name of political theology. ${ }^{45}$ Moreover, Mouffe in parts translates his theory into a poststructuralist vocabulary, and spells out more clearly than Schmitt that the friend/enemydistinction can be differentiated as types of primary and secondary (if not tertiary, etc.) level. From here, we can easily imagine political oppositions in the diagram form of a hierarchical tree; and this would certainly help us to overcome the one-dimensional binarity that the dichotomisation of friend and enemy in Schmitt's writings evokes, as well as to take seriously the interconnectedness of practices of political enunciation on various social levels.

(c) There is, however, a third criticism which reveals a real oddity. It concerns precisely Mouffe's attempt to back up Schmitt's conception with poststructuralism. Recent commentators have objected that transposing the poststructuralist logic of relational identity formation to politics would lead to a fairly different account because poststructuralism does not ground 
antagonism and the thesis of the impossibility of a rational consensus among political subjects. $^{46}$

Without delving into the technicalities of différance, the philosophical problem can be explained by highlighting Mouffe's quick move to assert that the self/other-relation in politics necessarily takes effect in the form of the construction of a 'we' which requires the exclusion of a 'them'. Proceeding from the assumption that identities are constructed and form relationally it clearly stands out that no all-inclusive identity could ever exist, because every identity requires a constitutive outside. Any 'self' requires the distinguishing reference to an 'other'. However, if Schmitt actually anticipates the idea of relational and constructed identity, as Mouffe suggests, ${ }^{47}$ then she appropriates this idea in his anthropomorphic version. For both Schmitt and Mouffe determine the political opponent to consist in an empirically specifiable group of actually existing concrete individuals. Yet, from a poststructuralist perspective, there is no need to equate the 'who/what' of the 'other' with the human. The 'other' is literally other. It might be found in a human being or a group of people, but there is no philosophical reason why it might not just as well be more or less fictional and abstract as the Martians or an uncontrolled nature of which novels tell us that they may unite mankind. Theoretically, the other might also be found in an animal, a plant, or a stone. ${ }^{48}$

To be sure, there is of course no compelling reason to expect that an animal, plant, or stone, an alien or natural force will ever motivate effective group adhesion. ${ }^{49}$ But this is an empirical, not a theoretical question. And that an 'other' can be constructed as something else than an empirically specifiable group of actually existing concrete individuals, and still be sufficient to mobilize a critical mass of people, is actually a less fanciful estimation than it 
might seem at first glance. Historical narratives are not entirely unreasonable, according to which the German nation in particular, and the European political community more generally, have constructed (part of) their identities along temporal lines and put themselves into opposition to a cruel past they seek to leave behind. ${ }^{50}$ And in the arguably not ineffective fascist propaganda writings of Giovanni Gentile the decisive enemy is the solidified collective self; the 'old Italian' that must continuously be sought to be overcome by and within each individual. ${ }^{51}$ The point is that from a poststructuralist perspective the 'other' is always a porous and somewhat phantasmatic projection, even if it is indicated by reference to a human collective. As such it is constantly being re-negotiated from within rather than characterised by an accomplished exclusion of any physical exteriority. ${ }^{52}$

Only because of the anthropomorphism can physical killing become the constitutive possibility of political struggles on Schmitt's account. And only because the friend/enemy-distinction is determined to concern human collectives can he present inter-state relations as less untransparent and perfidious than a politics of trans- or supranationalism. Mouffe sticks to the anthropomorphic determination of the friend/enemy-distinction, but she draws slightly different consequences from it. Even though she repeatedly emphasizes that violent conflict between political associations is an ever present possibility, at no point does one get the impression that politics finds its essence in it, or that Mouffe's agonistic pluralism is otherwise nourished by a bellicose teleology. Politics is not about war, but about the organization of the social space. The effective target of political action concerns the reconfiguration of hegemony, not the concrete agents of the hegemonic struggle. Even if the 'other' is conceptualized as a human entity, it is not 
necessarily conducive to one's cause to combat it in its physical existence. We know well enough that throughout history people have resorted to physical violence in order to reduce the socio-political influence of the respective 'other'. But we also know that to destroy an idea or to change a state of affairs by attacking its bearers does not always prove particularly effective. Sometimes, it actually causes counterproductive effects, as the history of Socrates, Jesus, or Giordano Bruno teaches.

The consequence that Mouffe does draw from the anthropomorphic determination of the friend/enemy-distinction, however, is that there cannot be an overall consensus without exclusions of concrete human beings. Schmitt is right, Mouffe says, 'that a political democracy cannot be based on the generality of all mankind, and that it must belong to a specific people', because 'the overcoming of [the] us/them opposition' by establishing an allinclusive consensus 'is impossible'. ${ }^{53}$ Yet, as we saw, a poststructuralist defanging of Schmitt's friend/enemy-distinction simply does not require the concretization of the 'other' to a 'them', which is to say, from a poststructuralist viewpoint the difference between self and other can well be theoretically constructed in a way as to include all human beings. The enactment of an effective cosmopolitan or global identity that includes all human beings 'may face many obstacles', Abizadeh concludes, 'but metaphysical impossibility and conceptual confusion are not among them'. ${ }^{54}$ Articulating such an identity certainly constitutes itself by the distinguishing reference to what it is not, and always excludes something in a problematic way. At least on the grounds of a poststructuralist ontology, in any case, it is plausible to let the excluded be the non-human, and to define it, for instance, by reference to animals, or gods, or both. 
Now, the critical question is why Mouffe sticks to an anthropomorphic version of the friend/enemy-distinction at all. Why does she arrive, contrary to reasonable expectations, at a significantly different conclusion from Derrida in his deconstruction of Schmitt's conception of the political? The commentators of Mouffe's dialogue with Schmitt who lay bare this oddity tend to suggest that Mouffe simply does not manage to deliver a consistent poststructuralist argument. Mouffe is found to 'inadvertently' inherit Schmittian essentialisms and to reproduce the 'reification of avoidable hostility'; to 'conflat[e] difference (Derrida) with alterity' and to elaborate a 'fallacious' argument. ${ }^{55}$ As I set out so far, I certainly agree that we can criticize Mouffe's dialogue with Schmitt in such a manner if we approach it exclusively from a systematic, analytical perspective; insofar as we are interested in the contribution of her agonistic pluralism to democratic theory and citizenship studies, or (because this is an arguably different thing) insofar as we are contemplating the possibility of a poststructuralist defanging of Schmitt's conception of the political. Yet, I am decidedly sceptical that this criticism persists to provide a convincing interpretation of Mouffe's dialogue with Schmitt and to understand the character of her academic intervention. ${ }^{56} \mathrm{We}$ need to ask ourselves whether Mouffe's anthropomorphic version of the friend/enemy-distinction is satisfyingly explained in terms of a failed transposition of Derrida's notion of différance to politics. It is puzzling indeed, as Fritsch notes, that Mouffe explicitly refers to poststructuralism, deconstruction, Derrida, and the notions of différance and the constitutive outside without ever happening to discuss Derrida's reading of Schmitt's friend/enemy-distinction, in which he rejects the anthropomorphism that then lives on in Mouffe's agonistic pluralism. ${ }^{57}$ Though puzzling, we may still 
wish to hesitate drawing the consequence that Mouffe unfortunately fails to understand or simply neglects Derrida's arguments. By going beyond Schmitt's political theory and calling to mind his contemplations about political theorizing, we can bring into focus another dimension of Mouffe's dialogue with Schmitt, and thus find a more plausible explanation for the anthropomorphic peculiarity that underlies her agonistic pluralism.

\section{The polemical dimension of Mouffe's dialogue with Schmitt}

At the Nuremberg trial Carl Schmitt emphatically affirmed that during the Nazi-Regime he had offered diagnostics of problems, not recommendations. He took refuge, as Caldwell expresses it, in the claim of pure science. Even indulgent contemporaries were not perfectly propitiated. To them his haranguing about Jews, for instance, made the impression of 'crude outbursts of political hate' rather than 'scholarly thes[e]s' as he retrospectively vindicated them. ${ }^{58}$ Additional doubts arise when taking seriously the function that Schmitt attributes in his writings to political theorizing. In The Concept of the Political Schmitt forthrightly denies the very possibility of offering dispassionate diagnostics. He stresses that 'all political concepts, images and terms have a polemical meaning' ${ }^{59}$ Theorizing, of course, is never a neutral act; all theory has normative implications. Yet Schmitt goes beyond this truism. Political theorizing is badly understood, in Schmitt's view, if grasped as offering pure diagnostics because politics is not only subjected to political theorizing, but also inbuilt. Rather than a collective attempt to resolve disagreement in opinion or nerve by the use of reason, political theorizing is a practical and partisan endeavour of staging disagreement by conceptual means. A political concept, he maintains accordingly, is 'incomprehensible if 
one does not know exactly who is to be affected, combated, refuted, or negated by such a term'. ${ }^{60}$

The polemical function thus attributed to political theorizing puts a new complexion on Mouffe's dialogue with Schmitt on the political. If Mouffe were to parallel Schmitt in this respect, too, then an interpretation of her dialogue with Schmitt cannot exclusively be characterized by depicting the shape and problems of her analytical arguments. Positively stated, if it is plausible that Mouffe appropriates the metatheoretical facet of Schmitt's intellectual heritage along with his conception of the political, then we have a better explanation for the divergence between Mouffe's and Derrida's respective deconstruction of the friend/enemy-distinction. For only the anthropomorphic version contains the political remainder that allows rejecting projects that aim at going beyond the adversarial model of a politics in the traditional left/right format. The critique of such projects, then, were to be evaluated not so much as the deduced implication of a (failed) poststructuralist reconstruction of Schmitt's conception of the political, but as one that is prompted from the outset and then realized by means of a theoretical recontextualization. So, what suggests that Mouffe really becomes inspired by Schmitt's remarks about the function of political theorizing?

Throughout her dialogue with Schmitt, it emerges clearly that Mouffe is concerned about the political lesson to be learnt from her theory. This is hardly surprising as Mouffe never made any pretence of her being leftist or 'left liberal', 61 and since affirming the practical importance of one's writings is paramount in the pursuance of good practice in the present academic conjuncture. What is required is textual evidence that exceeds the formulaic. A certain rhetorical impetus may be identified in the employment of 
essentialist language, which Mouffe does not seem eager to reduce to a minimum. ${ }^{62}$ While this is no rare phenomenon among academics, too, one might not expect this in writings that are repeatedly declared to be nonessentialist. ${ }^{63}$ More moving is an explicit statement at the beginning of On the Political. 'Although an important part of my argument is of a theoretical nature', Mouffe expounds here, 'my central aim is a political one'. ${ }^{64}$ Remarkably, the political message takes precedence over theory in this quotation. If the central goal of Mouffe's writings is a political one, then an analytical reconceptualization of Schmitt's political theory is subsidiary and instrumental. If nothing else, then this statement at least entertains the idea that Mouffe contents herself with proceeding from an ontology which is informed by, but not fully committed to poststructuralism, in order to synchronize diagnostics with polemics.

Less explicit, but likewise straightforward and, as it strikes me, highly resourceful is her emphasis on the term 'the political' itself. To see what I mean recall that while Schmitt affirms that concepts such as 'class', 'absolutism', or 'total state' never simply can be descriptive terms, ${ }^{65}$ he stresses that the 'political' is especially susceptible to polemicization. The use of the term 'political' itself, Schmitt claims, has no existence outside of a polemical practice:

'Above all the polemical character determines the use of the word political regardless of whether the adversary is designated as nonpolitical (in the sense of harmless), or vice versa if one wants to disqualify or denounce as political in order to portray oneself as nonpolitical (in the sense of purely scientific, purely moral, purely juristic, purely aesthetic, purely economic, or on the basis of similar purities) and thereby superior' ${ }^{66}$ 
Schmitt experienced that the term 'political' - plain or with a negative prefix - was frequently employed in the political discourse of his time to decontest one's partisan stance or disqualify an adversary. Schmitt felt that liberals, especially, availed themselves of the polemic susceptibility of the term. Designating their own policies as non-political, they discredited those of others as particularistic, partial, or immoral. Schmitt intended to change this situation. ${ }^{67}$ Notably, let us recall, not exclusively by delving into a foundationalist investigation about an alleged essence of the political. That would be obviously paradoxical if political theorizing has no existence outside of a polemical practice. Instead, Schmitt intended to challenge liberals' claim to moral supremacy by fielding the 'political' and 'non-political' as reconnoted metaphors, which is to say, by engaging in (counter-)polemicization.

It seems inconceivable that Mouffe could have glossed over Schmitt's remarks about the polemical dimension of theorizing, especially as they explicitly concern 'the political' which features so prominently in Mouffe's writings. If it is not excessive, then one might even feel that titles such as $O n$ the Political or The Return of the Political - rather than for instance 'On Democracy' or 'Towards an Agonistic Pluralism' - point to her intention of reviving Schmitt's conception in its simultaneously analytical and polemical character, and of embarking on a kindred strategy to intervene into (academic) political discourse.

Regarding the partisan stance Mouffe clearly does part company with Schmitt. Whatever the committment of Schmitt, the 'chameleon', ${ }^{68}$ was: fascist, militarist, volkstümlerisch, or simply nationalistic and ultraconservative. His position was definitely not left liberal or radical democratic. 
Mouffe could hardly find a fellow partisan in Schmitt. And it would be a crude neglect of the contingency of political discourse to tinker with the idea that she could find in him a brother in arms against a common enemy. Despite this partisan distance, however, the metatheoretical facet of Schmitt's intellectual heritage still gives Mouffe a key to reconfigure the discursive frontiers. His remarks, as becomes clear in the following, sparked off the idea to establish herself a we/them-opposition of her own by recontextualizing the polemical device of a political/non-political divide.

In her dialogue with Schmitt, Mouffe repudiates the projects of liberal and leftist philosophers, neoliberals and practitioners of the Third Way, right up to right-wing extremists, neoconservatives, and religious fundamentalists. A heterogeneous group indeed. She criticizes Habermas, Negri and Hardt for sympathizing with a cosmopolitan identity or rational consensus models; Beck, Giddens, and Blair for envisaging a politics beyond the adversarial model in the traditional left/right format, but also those who have rather concrete enemy images. Bush's idea to wage a war against terrorism was not political in character, she tells us. His was a moralist, messianic, and inherently non-political endeavour. ${ }^{69}$ She makes no substantial distinction between those who theorize about the possibility and desirability of a rational consensus - like representatives of philosophical liberalism - and politicians who just advertise their policies with rhetorical appeals to solidarity. Quite generally, she maintains, officials of main political parties reduce politics to 'spinning' and therefore likewise deplete the 'political' of its content. ${ }^{70}$ What justifies opposing this heterogeneity as a single collective identity is their respective negation of the 'political'. They all champion, as she puts it in slight modification of Schmitt, 'post-political visions'. 
Within a purely analytical framework which posits that the political is ubiquitous and permanent, of course, the category of the 'post-political' is not easily comprehensible. Likewise it is not intuitively clear whether a good/bad or right/wrong frame necessarily expresses or provokes fiercer oppositions than a left/right (or fascist/communist, socialist/capitalist, etc.) dualism. With a grain of linguistic nominalism it could be said that language is contingent upon use, and that thus the intensity of alternative dualistic frames depends on the hierarchical ordering in the concrete context. That 'the political' is both an analytical and polemic device in Mouffe's dialogue can finally be seen when we consider more closely what it means to negate the political. In first instance, it seems to testify to an escapist inclination because acknowledging the political is not a more demanding request than to face our 'ontological condition'. ${ }^{72}$ The impression of naivety is even more clearly conveyed where antagonism is diluted from being characterized as permanent, ineradicable, or irreducible to a possibility or potential (cf. endnote 30 ). To deny the political, then, amounts to renunciating even the last bit of commonsense realism. But when we are told that 'it is indeed the political, which is at stake here, and the possibility of its elimination', ${ }^{73}$ then we can easily see that acknowledging the 'political' is more than a realist imperative. The 'political', after all, cannot be eliminated if it is part of our ontological condition and only somebody who glorifies war could fear to lose it, were it the imminent peril of violent conflict. Cancellable are only the conditions for her radical-pluralist democratic vision: a democratic public sphere which allows for a nonviolent yet 'vibrant' clash of political positions. ${ }^{74}$ Adhering to her cause then is characterized as anything but a matter of reasonable choice or legitimate adversarial commitment. Once the term the political is connoted as that which 
most of us will appreciate - democracy, nonviolence, pluralism - those who (are professed to) 'deny the political' appear as the Trojan horses of antidemocratism. By aspiring to go beyond the adversarial model in its traditional left/right format they may not openly or consciously confront democracy. Yet, they are 'bound to miss the real task facing democratic politics' ${ }^{75}$

The irony is that Mouffe's application of the logic of inclusion/exclusion through the political/post-political divide reconfigures the frontiers of political discourse in a similarly (pseudo-)neutral - or, if you want, 'de-politicized' language that she criticizes so adamantly at political theorists and practitioners. Against the symbolic imagery of a politics beyond left and right, Mouffe works towards forging an alliance across the borders of the left and right. Actually, she takes the quest of framing one's partisan stance in a neutral language to its hilt: she constructs an 'other' that is not partisan but literally non-political (namely, 'post-political'); and she demarcates it from a 'self' that is not of any specific political character but the political itself.

\section{Concluding remarks}

In an interview with Ian Angus, Chantal Mouffe remembers 'I became a Gramscian when I ceased to be an Althusserian. And, in fact, Gramsci was for me a way to find a different approach' ${ }^{76}$ The point of this article is not to impose a new label and characterize her more recent work as Schmittian. To justify such a labelling, the differences between her purportedly 'Schmittian' writings to her other writings would have yet to be shown, and especially with her 'Gramscian' writings continuities can be expected anyway. Given the focus of this article on Mouffe's dialogue with Schmitt we can just raise questions such as whether her and Laclau's contemplation about strategy in 
hegemonic struggles now has found its way into a practical application. Suffice it to say that among the many possible authors of the writings that are traded under the name Chantal Mouffe there is one who deals with and gets inspired by the intellectual heritage of Carl Schmitt. That author appropriates portions of Schmitt's terminology and parts of his philosophical categories, prominently his anthropomorphic friend/enemy-distinction, but also conveys interest in the metatheoretical facet of his intellectual heritage with its emphasis on polemics. We have good reasons to believe that she has decided to adopt Schmitt's anthropomorphism in order to synchronize her theory of agonistic pluralism with a polemical intervention. This article proposes, therefore, to interpret Mouffe's dialogue with Schmitt as a contextualizing resurrection of his conception of the political, rather than a rigorous poststructuralist revision of his friend/enemy-distinction.

Let it be noted that no criticism is connected with this claim. Like sophistry and rhetoric, polemics often carry pejorative connotations in daily and scholarly usage. Instead of being scientific, sober, and relying on the force of reason, polemics is sometimes envisaged as populist, cynical, and frivolous. However, from the lasting debate about foundationalism the conclusion can be drawn that scholarship does not necessarily find its ideal in devising arguments that stand up to the expectations of the universal audience of a capitalized Reason or Truth. And even foundationalists seldom insist on a strict dichotomization of theory and practice, philosophy and rhetoric. ${ }^{77}$ On a nonfoundationalist spectrum, Mouffe's dialogue with Schmitt arguably gravitates more towards rhetorical-polarizing approaches than being committed to a pragmatist Darwinism, which recommends delivering theories to the test of practice. Still, even in Mouffe's case polemics do not crowd out 
proper theorizing. In contrast to Schmitt's account her agonistic pluralism never grounds the political in a bellicose teleology despite the insistence on the ineradicability of conflict among human collectives. Additionally, Mouffe more clearly breaks through the looming one-dimensionality of the friend/enemy-distinction by hierarchically differentiating at least a primary and secondary level of conflict.

We may of course legitimately argue against her metatheoretical stance, or decontest the partisan goals she adopts. Hers is a democratic struggle, after all, not the democratic one. And there is plenty of potential for such critique not only from allegedly 'post-political' viewpoints but from radical pluralist positions, too. While Mouffe calls for a vibrant clash of political positions within democracy, she does not precisely support the endogeneous negotiation of the democratic procedures. ${ }^{78}$ Tally remarks, in this sense, that citizens in Mouffe's vision of radical democracy assimilate players in organized sports rather than children on the playground who themselves negotiate the rules of the game. ${ }^{79}$ We may also underline the conceptual parallels in Schmitt's and Mouffe's accounts, or question Mouffe's reading of Schmitt. Or we may elaborate that proceeding from alternative ontologies leads to interestingly different results when revising the friend/enemy-distinction. As sketched above, a consequent deconstruction of the friend/enemy-distinction on the grounds of poststructuralism suggests that identities of every conceivable kind can be established through the différance of self/other and still be meaningfully characterized as political. Philosophically, there is nothing wrong with the Third Way's othering of a politics in the left/right format. Nor, we should add, is there anything wrong with Mouffe's radical pluralist inversion which insists on the traditional adversarial model, and ironically 
seeks to overcome factionism in a structurally similar way by displacing the opposition between the left and the right onto a secondary level. However, if we are to provide an interpretation of Mouffe's dialogue with Schmitt we would do well to refrain from reducing it to its analytical dimension and from criticizing it for not delivering the theoretical model one might favour. We should instead take into account its polemical dimension and its interwovenness with her theory of agonistic pluralism. And if we disagree in substance, then we should at least acknowledge the overall coherence of this unlikely account. When confronting associative conceptions of the political with a dissociative one, after all, it is a quite compelling move to make one's case in a manner that is itself dissociative and not conciliating or consensusoriented, which is to say, in a polemical rather than irenical way. 


\section{Notes}

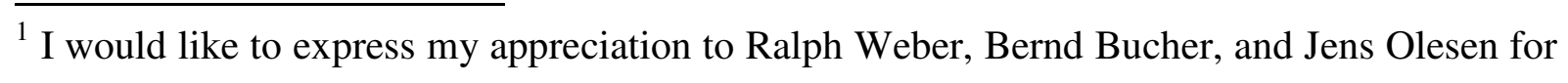
critical and useful comments on earlier drafts of this article.

${ }^{2}$ C. Mouffe, On the Political (London/ New York: Routledge, 2005), p. 4.

${ }^{3}$ Mouffe's dialogue with Schmitt primarily takes place in the following works: The Return of the Political (1993), esp. ch. 7-9; The Challenge of Carl Schmitt (1999), introduction and ch. 3; and On the Political (2005). Given the multiplicity of writings, it might be more adequate to speak of dialogues in the plural. For the central argument of this article, however, the similarities of such dialogues carry more weight than the differences so that I consider it legitimate to portray them as a more or less coherent unity.

${ }^{4}$ E.g. B. Arditi, 'On the Political. Schmitt Contra Schmitt', Telos 142 (2008), pp. 7-28, esp. pp. 9-11; J.S. Dryzek and S. Niemeyer, 'Reconciling Pluralism and Consensus as Political Ideas', American Journal of Political Science 50 (2006), pp. 634-49; M. Fritsch, 'Antagonism and Democratic Citizenship (Schmitt, Mouffe, Derrida)', Research in Phenomenology 38 (2008), pp. 174-197; J. Torfing, New Theories of Discourse. Laclau, Mouffe and Žižek (Oxford: Blackwell, 2003), p. 121; M.A. Wenman, '»Agonistic Pluralism « and Three Archetypal Forms of Politics', Contemporary Political Theory 2 (2003), pp. 165-86, esp. p. 179.

${ }^{5}$ C. Mouffe, The Challenge of Carl Schmitt (London: Verso, 1999), pp. 1-2; Mouffe [OP], op. cit., Ref. 2, pp. 4-5.

6 The term 'dissociative' refers to Oliver Marchart's differentiation of Schmittian approaches to the political from those of Arendtian traditions that emphasize the 'associative' aspect of acting together. O. Marchart, Post-Foundational Political Thought. Political Difference in Nancy, Lefort, Badiou and Laclau (Edinburgh: Edinburgh University Press, 2007), pp. 3843.

${ }^{7}$ Honig conceptualizes her version of agonistic pluralism in, for instance, Political Theory and the Displacement of Politics (New York: Cornell, 1993) and 'The Politics of Agonism: A Critical Response to »Beyond Good and Evil: Arendt, Nietzsche, and the Aestheticization of Political Action« by Dana R. Villa', Political Theory 21 (2003), pp. 528-533. For a thoroughgoing discussion of the differences between Mouffe's, Connolly's, and Tully's 
conceptions of agonistic pluralism, see Wenman, op. cit., Ref. 4. For a broader overview of positions associated with agonistic pluralism, see A. Schaap, Law and Agonistic Politics (Farnham: Ashgate, 2009).

${ }^{8}$ M. Weber, Economy and Society (Berkeley: University of California Press, 1978), vol. 1/I, 17, p. 55.

${ }^{9}$ C. Schmitt, The Concept of the Political (Chicago: University of Chicago Press, 1996), pp. 25-6.

${ }^{10}$ C. Mouffe, The Return of the Political (London: Verso, 1993), p. 3; Mouffe [OP], op. cit., Ref. 2, p. 16.

${ }^{11}$ Mouffe [RP], op cit., Ref. 10, pp. 2-3, 110, 140; Mouffe [CS], op. cit., Ref. 5, p. 4; Mouffe [OP], op. cit., Ref. 2, pp. 5, 11.

${ }^{12}$ Mouffe [RP], op cit., Ref. 10, pp. 2, 114, 152; Mouffe [CS], op. cit., Ref. 5, pp. 4, 43; Mouffe [OP], op. cit., Ref. 2, pp. 15, 18.

${ }^{13}$ Mouffe (CS), op. cit., Ref. 5, pp. 4-5; cf. also Mouffe (RP), op cit., Ref. 10, pp. 4-5; Mouffe (OP), op. cit., Ref. 2, p. 14.

${ }^{14}$ Mouffe [CS], op. cit., Ref. 5, p. 48; Mouffe [OP], op. cit., Ref. 2, p. 14.

15 E.g. G. Sartori, 'The Essence of the Political in Carl Schmitt', Journal of Theoretical Politics 1 (1989), pp. 63-75; J. Derrida, Politics of Friendship (London: Verso, 1997); Arditi, op. cit., Ref. 4.

${ }^{16}$ R. Geuss, History and Illusion in Politics (Cambridge: Cambridge University Press, 2001), pp. 4-5.

${ }^{17}$ Schmitt [CP], op. cit., Ref. 9, p. 33.

${ }^{18}$ Schmitt, ibid., p. 34.

${ }^{19}$ Sartori, op. cit., Ref. 15, pp. 66-8; Derrida, op. cit., Ref. 15, pp. 131-2; Arditi, op. cit., Ref. 4, p. 8 .

${ }^{20}$ Schmitt [CP], op. cit., Ref. 9, p. 36. 
${ }^{21}$ Instead of the abridged dictum of Clausewitz 'war is the continuation of politics by other means', Schmitt insists on the literal translation '[w]ar is nothing but a continuation of political intercourse with a mixture of other means' (Schmitt, ibid., p. 34 Fn. 14). I doubt that there are significant differences in the two phrases for Schmitt's argument.

${ }^{22}$ C. Schmitt, Der Begriff des Politischen. Text von 1932 mit einem Vorwort und drei Corollarien (Berlin: Duncker\&Humblot, 2002), p. 107.

${ }^{23}$ Mouffe [CS], op. cit., Ref. 5, p. 49.

${ }^{24}$ Mouffe [OP], op. cit., Ref. 2, p. 20.

${ }^{25}$ C. Mouffe, 'Citizenship and Political Identity', October 61 (1992), pp. 28-32, here p. 31.

${ }^{26}$ Mouffe [CS], op. cit., Ref. 5, p. 4; C. Mouffe, Deliberative Democracy or Agonistic Pluralism (Vienna: Institute for Advanced Studies, 2000), p. 26; Mouffe [OP], op. cit., Ref. 2, p. 52.

${ }^{27}$ Mouffe [CS], op. cit., Ref. 5, p. 50. In other passages Mouffe writes that people in democratic societies accept the 'principles of modern pluralist democracy, i.e. [...] liberty and equality for all' (Mouffe, op. cit., Ref. 25, p. 30), or share a common allegiance to the 'ethicopolitical principles of liberal democracy' (Mouffe [CS], op. cit., Ref. 5, p. 4).

${ }^{28}$ Mouffe [OP], op. cit., Ref. 2, p. 2.

${ }^{29}$ Arditi, op. cit., Ref. 4, p. 10; I. Kapoor, 'Deliberative Democracy or Agonistic Pluralism? The Relevance of the Habermas-Mouffe Debate for Third-World Politics', Alternatives 27 (2002), pp. 459-87, here pp. 472-3; J. S. Dryzek, Deliberative Global Politics. Discourse and Democracy in a Divided World (Cambridge: Polity Press, 2006), p. 221.

${ }^{30}$ Compare the inconsistent statements at Mouffe [RP], op cit., Ref. 10, pp. 3, 8; Mouffe [CS], op. cit., Ref. 5, p. 4; Mouffe [OP], op. cit., Ref. 2, pp. 12-16. Cf. Arditi, op. cit., Ref. 4, p. 10.

${ }^{31}$ Mouffe [OP], op. cit., Ref. 2, pp. 2, 76-8, 116, 120. 
${ }^{32}$ Mouffe, ibid., p. 120.

${ }^{33}$ Mouffe [CS], op. cit., Ref. 5, p. 4.

${ }^{34}$ This criticism is explicitly levelled by Arditi, op. cit., Ref. 4, p. 10.

${ }^{35}$ Schmitt [CP], op. cit., Ref. 9, pp. 19-20.

${ }^{36}$ Schmitt dedicates a whole theory to the partisan (C. Schmitt, Theory of the Partisan. Intermediate Commentary on the Concept of the Political [New York: Telos, 2007]). Moreover, in his Italian 1972 preface to The Concept of the Political, Schmitt explicitly writes: 'The new protagonists become the core of the entire complex of problems called $»$ political «. Here lies the beginning and thrust of every attempt to recognize the many new subjects of the political, which become active in political reality, in the politics of the state or nonstate, and which bring about new kinds of friend-enemy groupings' (Schmitt quoted in Marchart, op. cit., Ref. 6, p. 42).

37 Marchart, op. cit., Ref. 6, p. 43. Cf. Schmitt [CP], op. cit., Ref. 9, p. 22.

${ }^{38}$ Schmitt, op. cit., Ref. 22, pp. 117, 120.

${ }^{39}$ Schmitt [CP], op. cit., Ref. 9, p. 30; cf. also C. Schmitt 'Ethic of State and Pluralistic State', in: Mouffe [CS], op. cit., Ref. 5, pp. 195-208.

${ }^{40}$ Schmitt [CP], op. cit., Ref. 9, p. 30.

${ }^{41}$ C. Schmitt, The Crisis of Parliamentary Democracy (Cambridge, Mass.: MIT Press, 2000), p. 9.

${ }^{42}$ Mouffe, op. cit., Ref. 25, pp. 30-1; Mouffe [RP], op cit., Ref. 10, pp, 4, 67; Mouffe [OP], op. cit., Ref. 2, pp. 32, 52, 122.

${ }^{43}$ In his self-apologetic preface to the 1963 German edition of The Concept of the Political Schmitt assures the reader that the decisive challenge is the limitation of war which requires the mutual relativization of enmity (Schmitt, op. cit., Ref. 22, p. 19). In the Theory of the Partisan he points out that by the 'relativization of enmity' he understands the 'renunciation 
of the criminalization of the opponent [...], the negation of absolute enmity', or the abjuration of 'a discrimination and denigration of the enemy' - something which had paradigmatically been accomplished, in his view, in the Jus Publicum Europaeum of the Westphalian System until 1815 (Schmitt, op. cit., Ref. 36, p. 90). Having neglected to specify explicitly different types of enemies is the reason, Schmitt explains, for the negative reception of his work. The 'enemy' he wanted to talk about is the 'real enemy' which is 'an enemy who [...] must be compelled only to retreat into his borders', not one who must be definitively destroyed (Schmitt [CP], op. cit., Ref. 9, p. 3-7; also quoted in Schmitt, op. cit., Ref. 36, p. 93 Fn. 93). Giovanni Sartori argues that Schmitt thus places an incompatible 'historical' argument next to his 'logical' one (Sartori, op. cit., Ref. 15, p. 67 Fn. 7). It seems that Mouffe reproduces this paradox rather than solving it.

44 'Die ritterliche Fehde führt zu festen Formen und damit auch zur agonalen Auffassung des Fehdegegners' (Schmitt, op. cit., Ref. 22, pp. 104-5).

45 P. C. Caldwell, 'Controversies Over Carl Schmitt. A Review of Recent Literature', The Journal of Modern History 77 (2005), pp. 357-87, here p. 363. Also, it should be noted that Mouffe especially draws on writings such as The Crisis of Parliamentary Democracy, and Ethic of State and Pluralist State, in which the need for homogeneity of the citizenry is emphasized (Mouffe [CS], op. cit., Ref. 5, pp. 41-8).

${ }^{46}$ A. Abizadeh, 'Does Collective Identity Presuppose an Other? On the Alleged Incoherence of Global Solidarity', American Political Science Review 99 (2005), pp. 45-60; Fritsch, op. cit., Ref. 4.

${ }^{47}$ Mouffe [OP], op. cit., Ref. 2, pp. 14-5. Gabriella Slomp comes to the same conclusion as Mouffe (G. Slomp, 'Carl Schmitt on Friendship. Polemics and Diagnostics', Critical Review of International Social and Political Philosophy 10 [2007], pp. 199-213, here p. 208). But see Caldwell for an argument to the contrary (Caldwell, op. cit., Ref. 45, pp. 367, 382). 
$\overline{{ }^{48} \text { J. Derrida, ‘»Eating Well, « or the Calculation of the Subject', in: E. Weber (ed.), Points... }}$ Interviews 1974-1994 (Stanford: Stanford University Press, 1995), pp. 255-87, here pp. 2689.

49 A. Lefebvre, 'The Political Given. Decisionism in Schmitt's Concept of the Political', Telos 132 (2005), pp. 83-98.

50 Abizadeh, op. cit., Ref. 46, p. 58. See also Ole Waever (O. Waever, 'Discursive Approaches', in: A. Wiener and T. Diez (eds.), European Integration Theory [Oxford: Oxford University Press, 2003], pp. 197-215, here p. 210). Such forms of identities can be said to rest on temporal differentiation. Thus, the 'self' is defined in relation to itself, yet along the axis of past, present, and future.

${ }^{51}$ G. Gentile, Guerra e fede. Frammenti politici (Napoli: Ricciardi, 1919), p. 67.

${ }^{52}$ Derrida, op. cit., Ref. 15, p. 11; Fritsch, op. cit., Ref. 4, p. 188.

${ }^{53}$ C. Mouffe, The Democratic Paradox (London: Verso, 2000), pp. 40, 45.

${ }^{54}$ Abizadeh, op. cit., Ref. 46, p. 45; cf. Fritsch, op. cit., Ref. 4, p. 184.

${ }^{55}$ Fritsch, ibid., pp. 184, 196; Abizadeh, op. cit., Ref. 46, p. 45.

${ }^{56}$ Given that Abizadeh and Fritsch have primarily systematic interests, these remarks are not intended as criticisms of their overall argument(s). At least Fritsch's comment suggests, however, that Mouffe's dialogue with Schmitt is adequately interpreted as a (failed) analytical attempt to substantiate an anthropomorphic friend/enemy-distinction along poststructuralist lines: 'The claim as to the necessarily antagonistic exclusion of concrete others can be supported neither on its own terms nor on Derridian grounds, as Chantal Mouffe, in particular, attempts to do' (Fritsch, op. cit., Ref. 4, p. 174; emphasis added).

${ }^{57}$ Fritsch, ibid., p. 188.

${ }^{58}$ H. Quaritsch, Carl Schmitt. Antworten in Nürnberg (Berlin: Duncker\&Humblot, 2000), pp. 53-5; Caldwell, op. cit., Ref. 45, p. 382. 
${ }^{59}$ Schmitt [CP], op. cit., Ref. 9, p. 30.

${ }^{60}$ Schmitt, ibid., p. 31. In the more radical interpretation of Hefler, political theorizing for Schmitt finds its primary and sufficient raison d'être in polemics. G. Hefler, 'Wissenschaftlichkeit als Einsatz. Methodologie als politische Strategie bei Carl Schmitt und Hans Kelsen', in: W. Pircher (ed.), Gegen den Ausnahmezustand. Zur Kritik an Carl Schmitt (Wien/New York: Springer, 1999), pp. 249-84, esp. pp. 250, 276.

${ }^{61}$ Mouffe [CS], op. cit., Ref. 5, p. 5.

${ }^{62}$ Mouffe frequently refers, for instance, to the social, pluralist, discursive, or conflictual 'nature' of social life, citizenship, or democracy; she tells us how things are 'by essence' or 'essentially', or reminds us of questionable 'facts'. Mouffe [RP], op cit., Ref. 10, pp. 2, 8, 30, 33, 57, 70, 104, 111, 115, 117; Mouffe [OP], op. cit., Ref. 2, pp. 15, 17, 18, 31, 38, 54, 56, 83, 120.

${ }^{63}$ Mouffe [RP], op cit., Ref. 10, pp. vii, 71; Mouffe, op. cit., Ref. 25, p. 28; Mouffe [CS], op. cit., Ref. 5, series description; Mouffe [OP], op. cit., Ref. 2, p. 4.

${ }^{64}$ Mouffe [OP], op. cit., Ref. 2, p. 9.

${ }^{65}$ Schmitt [CP], op. cit., Ref. 9, pp. 30-1.

${ }^{66}$ Schmitt, ibid., pp. 31-2.

67 B. Arditi and J. Valentine, Polemicization. The Practice of Afoundationalism (Edinburgh: Edinburgh University Press, 1999), p. 38.

${ }^{68}$ K. Schultes, Der Niedergang des staatsrechtlichen Denkens im Faschismus (Weimar: Werden und Wirken, 1947), p. 12.

${ }^{69}$ Mouffe [OP], op. cit., Ref. 2, pp. 77-9.

${ }^{70}$ Mouffe, ibid., p. 63.

${ }^{71}$ E.g. Mouffe, ibid., pp. 48, 60-1, 110.

${ }^{72}$ Mouffe, ibid., p. 16. 
${ }^{73}$ Mouffe [RP], op cit., Ref. 10, p. 1.

${ }^{74}$ Mouffe [RP], ibid., p. 6; Mouffe [DP], op cit., Ref. 53, p. 104; Mouffe [OP], op. cit., Ref. 2, p. 71.

${ }^{75}$ Mouffe [OP], op. cit., Ref. 2, p. 2.

${ }^{76}$ I. Angus, 'An Interview with Chantal Mouffe and Ernesto Laclau', Transcript. From the Television Series 'Conflicting Publics' on Knowledge Network (http://www.ianangus.ca/, accessed 23 January 2010).

${ }^{77}$ M. Brint, W. G. Weaver, and M. Garmon, 'What Difference Does Anti-Foundationalism Make to Political Theory?', New Literary History 26 (1995), pp. 225-237.

${ }^{78}$ While it is fair enough that pluralism necessarily 'requires discriminating between demands which are to be accepted as part of the agonistic debate and those which are to be excluded' (Mouffe [OP], op. cit., Ref. 2, p. 120), it is quite another thing to claim that those within a society that do not accept the hegemonically instituted rules of the game 'thereby exclude themselves from the political community' (Mouffe [RP], op cit., Ref. 10, p. 4, emphasis added).

${ }^{79}$ R. T. Tally, 'The Agony of the Political', Postmodern Culture 17 (2007). 